\title{
IDENTIFICATION OF WATER INUNDATION USING QUICKBIRD AND ALOS PALSAR SATELLITE IMAGE STUDY CASE: DAYEUHKOLOT SUBDISTRICT, BANDUNG DISTRICT
}

\author{
Identifikasi Genangan Air Dengan Citra Quickbird dan Alos Palsar \\ (Studi Kasus: Kecamatan Dayeuhkolot, Kabupaten Bandung) \\ Maundri Prihanggo', Sony Darmawan ${ }^{2}$, Ketut Wikantika² \\ ${ }^{1}$ Geospatial Information Agency \\ ${ }^{2}$ Center for Remote Sensing, Institute Technology of Bandung (ITB), Indonesia \\ E-mail: maundri.prihanggo@big.go.id
}

Diterima (received): 16 Oktober 2014; Direvisi(revised):30 Oktober 2014;Disetujui dipublikasikan (accepted):7 November 2014

\begin{abstract}
Indonesia was one of many disasterous potential country, more than $70 \%$ of natural disaster happened werehidrometeorogical disaster includingflood. Flood is definedas an overflow or inundation that comes from a river or other body of water and causes or threatens damage, any relatively high streamflow overtopping the natural or artificial banks in any reach of a stream. There are 4 regionsin Java Island that havethe highest potention of flood, they are Jakarta Province, Merapi Slope Area, Bengawan Solo and Citarum Watershed Area. The purpose of this study is to identify land cover and water inundation of the study area using Quickbird and ALOS PALSAR image. Before classified and analyze the result, image pre-processing has to be generated in Quickbird and ALOS PALSAR image data to rid off thedistorsion from the data. Quickbird Image can be used for land cover identification with generated object based image classification and ALOS PALSAR Image are applied to identify water inundation in flood area using backscatter value deliniation. By 10th September 2013 with only $5 \mathrm{~mm}$, all of the classes were inundated by water at severalvalues.
\end{abstract}

Keywords: water inundation, remote sensing, Quickbird, ALOS PALSAR.

\begin{abstract}
ABSTRAK
Indonesia merupakan salah satu negara yang memiliki potensi bencana yang cukup tinggi dan lebih dari $70 \%$ bencana yang terjadi merupakan bencana hidrometeorologis termasuk banjir. Banjir didefinisikan sebagai luapan atau genangan yang keluar dari sungai atau badan air dan menyebabkan suatu bahaya dan disebabkan oleh fenomena cuaca dan kejadian yang menyebabkan presipitasi berlebihan pada suatu permukaan bumi. Di Pulau Jawa terdapat empat daerah rawan banjir yang mendapat prioritas tinggi yaitu lereng Gunung Merapi, Provinsi Jakarta dan Daerah Aliran Sungai Bengawan Solo serta Daerah Aliran Sungai Citarum. Tujuan dari studi ini adalah melakukan identifikasi tutupan lahan daerah kawasan banjir beserta luasan genangan air pada tiap tutupan lahan dengan memanfaatkan citra Quickbird dan citra ALOS PALSAR. Sebelum dilakukan proses klasifikasi dan analisis citra, proses pra pengolahan data dilakukan pada citra Quickbird dan ALOS PALSAR agar bersih dari kesalahan yang ada. Tutupan lahan akan didapatkan dari citra Quickbird dengan metode klasifikasi object based dan genangan air diperoleh dengan deliniasi nilai backscatter citra ALOS PALSAR. Dengan curah hujan $5 \mathrm{~mm}$ pada tanggal 10 September 2007 seluruh kelas pada area studi tergenang dengan nilai tertentu.
\end{abstract}

Kata kunci: genangan air, penginderaan jauh, Quickbird, ALOS PALSAR.

\section{INTRODUCTION}

Flood has been an annual disaster in Indonesia. Indonesia which located along the equatorial line has two seasons, rainy season could cause flood as one of the hidrometeorogical disaster. From the total of 703 disasters happened through the year of 2012, there are 193 flood occured in Indonesia. Flood is defined as an overflow or inundation that comes from a river or other body of water and causes or threatens damage and there are four regions in Java Island that government has been focusing since 2012, one of them is along Citarum Watershed.
Remote sensing is defined as the science and art of obtaining information about an object, area, or phenomenon through the analysis of data acquired by a device that is not in contact with the object, area, or phenomenon under investigation (Lillesand and Kiefer, 1979) has many applications in human activities. In the early development of remote sensing, Landsat TM and SPOT imageries became the primary source of data for monitoring floods and deliniating the boundary of inundation. Then, the existence of cloud cover appears as the single most important impediment to capture the progress of floods in bad weather condition (Rango et al., 1977). The development of microwave remote sensing, 
particularly radar imageries, solved the problem because it could penetrate cloud. In recent years, both optical and microwave remote sensing has been used to map flood because of its advantages. Uddin et al (2008) use ENVISAT ASAR and ASTER Images to create flood damage map in Sunsari District, Nepal. From ASTER Images, the author could make Sunsari District land cover and get the flood extend map from ENVISAT ASAR. By fusing land cover and flood map, the author makes flood damage map to measure the damage occured in Sunsari District, Nepal. Harun et al (2009) also combined the use of passive and active sensor to mapflood in Dhaka City, Bangladesh.

The purpose of this study is to learn the application of remote sensing to identify and to measure water inundation using Quickbird and ALOS PALSAR Image in south of Bandung.

\section{Study Area And Data}

The study area is located in south of Bandung along Citarum Watershed. It broads $8.169 \mathrm{~km}^{2}$ and lies at elevation $662.5-675 \mathrm{~m}$ above mean sea level as shows in figure 1 . By visiting the study area, it is found that most of the land is used for house settelement, industrial building and agriculture. Figure 2 shows the topography of study area and rainfall occuredduring 2007-2009 in Bandung District shown in figure 3.

Data used in this study are Quickbird and ALOS PALSAR Image. Quickbird Image took in the $6^{\text {th }}$ of October, 2009 and refer to geodetic datum WGS 84 with Universal Transverse Mercator coordinate system and TM- $6^{\circ}$ projection system. Quickbird Image has 0.6 meter spatial resolution with three visible light band (red, gree, blue). ALOS PALSAR Image took time in September $11^{\text {th }}$ 2007 and at the level 1.5 with 6.25 meter spatial resolution.

Bandung Regency Monthly Rainfall during 2006-2007

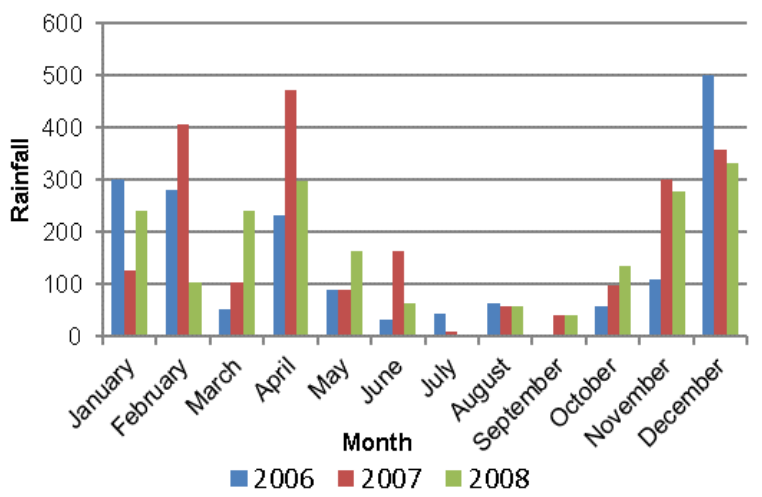

Figure 1. Rainfall in Bandung Regency (source: geophysics and meteorology station data)

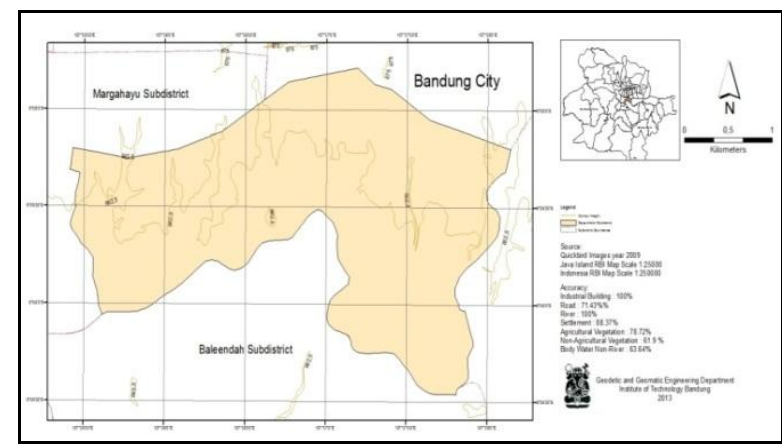

Figure 2. Topography of study area

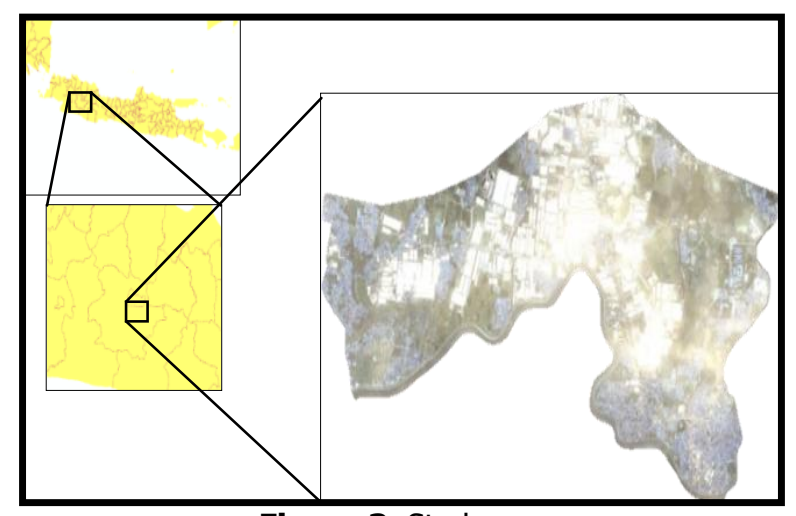

Figure 3. Study area

\section{METHODS}

Methods used in this study are shown in figure 4. In this methods, DEM data of the study area was not used, by using DEM data it might gain the accuracy of water inundated area. Quickbird Image used toproduce land cover of study area. Image preprocessing consists of geometric correction, image cropping and image strecthing. Geometric correction generated in this methodis used for eliminate error occured while capturing data.

By using 13 GCPs and 5 ICPs with RMSe 0.94 and 0.93, Quickbird image had geometrically corrected to Universal Transverse Mercator Zone $48 \mathrm{~S}$ projection system and World Geodetic System 84 datum. Quickbird image has been croppedappropriately according to skecth from Dayeuh Kolot Subdistrict. To increase the quality of image, histrogram strecth with range value $3 \sigma$ (standard deviation) is generated. To classify Quickbird image data, object based method is used in this study.

There are two basic steps in object based method, which are segmentation and classification. Image segmentation used to clustered Quickbird image data based on five parameters. They are parameter scale, color, shape, smoothness and compactness. There are some methods in object based image classification, one of it is nearest neighbour method. Nearest neighbor method is performed in this study and to increase the quality of classification, some characteristic of class's 
classified has to be differentiate by input some feature paramaters. Feature paramaters in image segmentation and image classification are shown in table 1 and table 2.

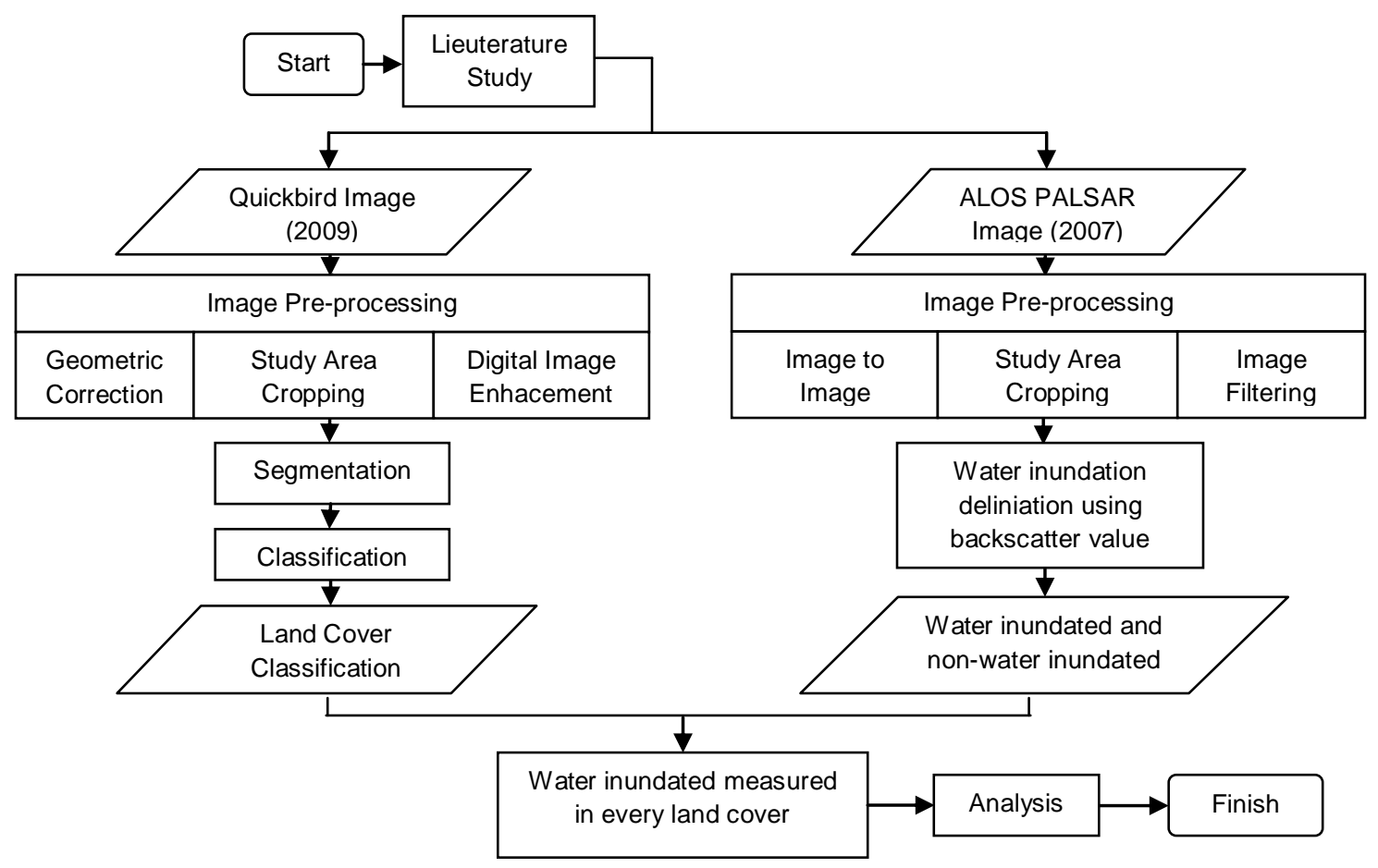

Figure 4. Methdology used in this study

Tabel 1. Feature Paramater in Image Segmentation

\begin{tabular}{c|ccccc}
\hline Image segmentation & Scale Paramater & Color & Shape & Compactness & Smoothness \\
\hline Value & 60 & 0.1 & 0.9 & 0.1 & 0.9 \\
\hline
\end{tabular}

Table 2. Image Classification

\begin{tabular}{ccccccccc}
\hline Feature paramater & \multicolumn{2}{c}{ Brightnes } & \multicolumn{2}{c}{ Length/width } & Main direction & Shape index & \multicolumn{2}{c}{ Area } \\
\hline River & $\geq 117$ & $\leq 232$ & - & - & $>8$ & $\geq 1.3$ & $<5.2$ & $>505$ \\
Road & - & - & $\geq 1.6$ & $\leq 14.9$ & - & - & - & - \\
Settlement & $\geq 155$ & $\leq 246$ & - & - & - & & \\
Agriculuture Vegetation & - & - & - & - & - & & - & - \\
Non-Agriculture Vegetation & $\geq 119$ & - & - & - & - & - & - & - \\
Industrial Building & $>225$ & $\leq 255$ & - & - & - & - & - \\
\hline
\end{tabular}

Image pre-processing used in ALOS PALSAR image are image to image geometric correction, study area cropping and image filtering. Image to image geometric correction used to adjust ALOS PALSAR image into the same reference coordinate with Quickbird image. There are 7 GCPs chosen in image to process imagewith 0.755 RMSe. Data used in ALOS PALSAR have to have exact border with Quickbird image. Therefore, study area cropping process has to be generated in high precision. Noise occured while capturing the image in SAR satellite could decrease the quality of the image, image filtering generated to remove the noise (Sarode and Desmukh, 2011).

Image filtering generated in this study was enhanced lee image filter because of its advantages to delineate water area, less highfrequency noise, more homogenous water features, less "salt and pepper"-structures (Twele et al., 2009). To differentiate water and nonwater in ALOS PALSAR image, deliniation in ALOS PALSAR imageis performed by putting threshold in digital number value of backscatter. The minimum value istaken as the lower threshold and the upper threshold is the mean number value (Hidayat et al., 2012).

After taking samples from ALOS PALSAR image, the lower threshold is 554 and the upper threshold is 4153 . Samplesareidentified as body water or water inundation in study area. Image pre-processing used in ALOS PALSAR image are image to image geometric correction, study area cropping and image filtering. Image to image geometric correction used to adjust ALOS PALSAR image into the same reference coordinate with Quickbird image. There are 7 GCPs chosen in 
image to process image with 0.755 RMSe. Data used in ALOS PALSAR have to have exact border with Quickbird image. Therefore, study area cropping process hasto be generated in high precision. Noise occured while capturing the image in SAR satellite could decrease the quality of the image, image filtering generated to remove the noise (Sarode and Desmukh, 2011). Image filtering generated in this study was enhanced lee image filter because of its advantages to delineate water area, less high-frequency noise, more homogenous water features, less "salt and pepper"-structures (Twele et al., 2009).

To differentiate water and non-water in ALOS PALSAR image, deliniation in ALOS PALSAR imageis performed by putting threshold in digital number value of backscatter. The minimum value istaken as the lower threshold and the upper threshold isthe mean plus one standard deviation of samples's digital number value (Hidayat et al., 2012). After taking samples from ALOS PALSAR image, the lower threshold is 554 and the upper threshold is 4153. Samples are identified as body water or water inundation in study area.

\section{DISCUSSION}

The classification results for land cover and water inundation map are shown in figure 6 and figure 5. Using Quickbird image to get land cover of study area is commonly used and the combination of ALOS PALSAR image improves the assesment of water inundation in study area. It is one of the ALOS PALSAR strengths, such as the ability of ALOS PALSAR satellite that can not be affected by weather and the sensitivity of water reflection. Total area affected by water inundation shows by table 2 and water inundation damage map shows by figure 7. From the result, the highest area affected by water inundation is agriculture vegetation and the lowest is settlement.

Agriculture and non-agriculture vegetation had some area that were inundated by water because of its phase and bad drainage system, are show in figure 8. Industrial building was the second biggest of its area which is inundated by water, this could be because of the topography of the study area that only lies at around $662.5 \mathrm{~m}$ above mean sea level. The maximum difference between the highest and lowest point in study area is 12.5 meter. The time difference in data taken between Quickbird and ALOS PALSAR image is also affecting the result. Quickbird image was taken by the 10th of September 2009. While ALOS PALSAR image by the 10th of September 2007. It cause difference in classification results produced by those image.Those results produce by the data are difference in its land cover. Data pre-processing in those two image data are also affecting the result. ALOS PALSAR image to image geometric correction is using Quickbird image as the reference. This could cause changes in ALOS PALSAR metadata and its spatial resolution is changed from 6.25 meter to 0.6 meter. Because the method used for image resampling is the nearest neighbour, the result pixel's digital number value is taken from the nearest pixel's digital number before processed. It is caused at some point, ALOS PALSAR image does not exactly represent water inundation's digital number.

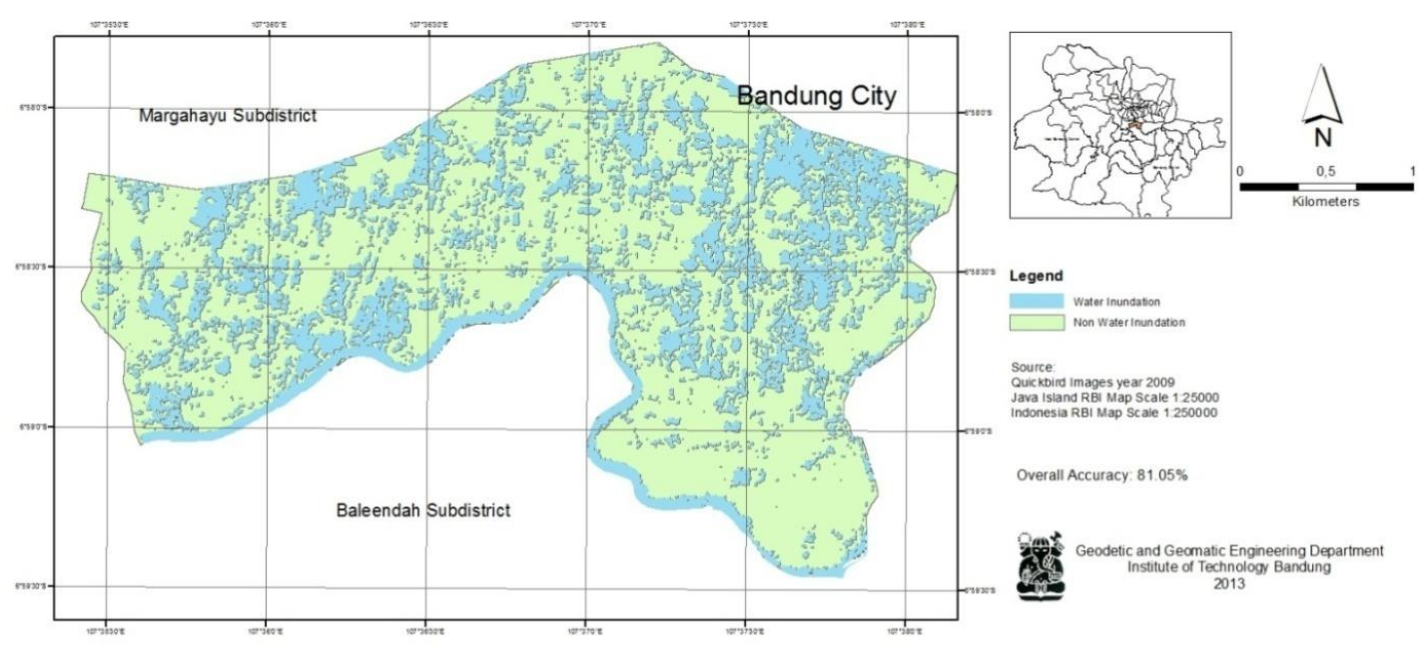

Figure 5. Water inundation map using ALOS PALSAR image year 2007 


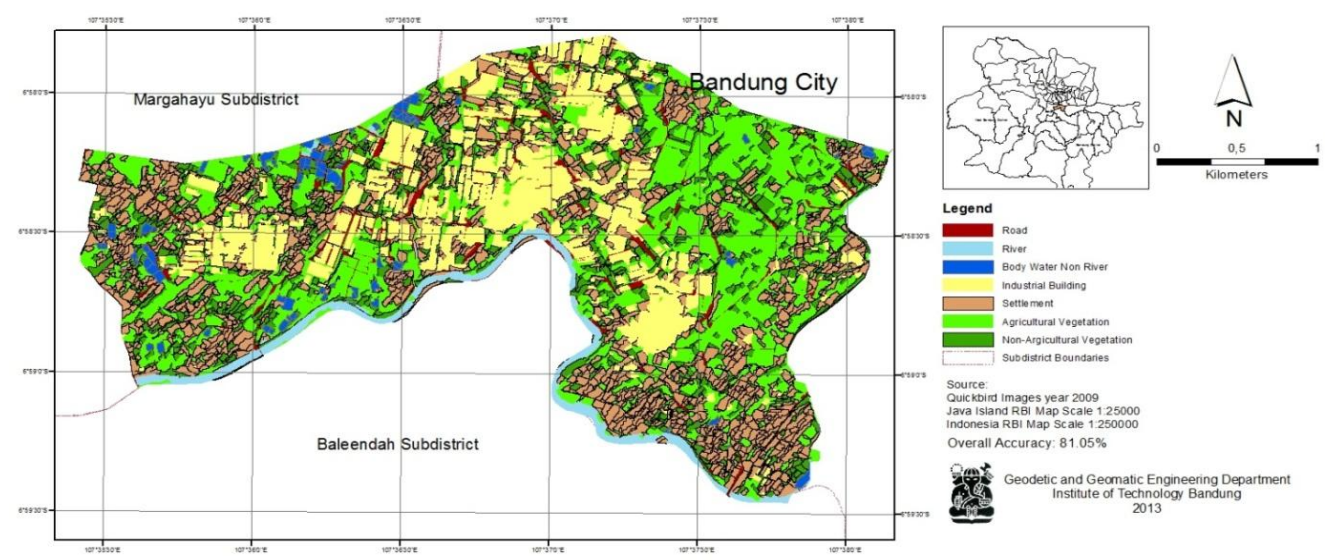

Figure 6. Classfication map using Quickbird image year 2009

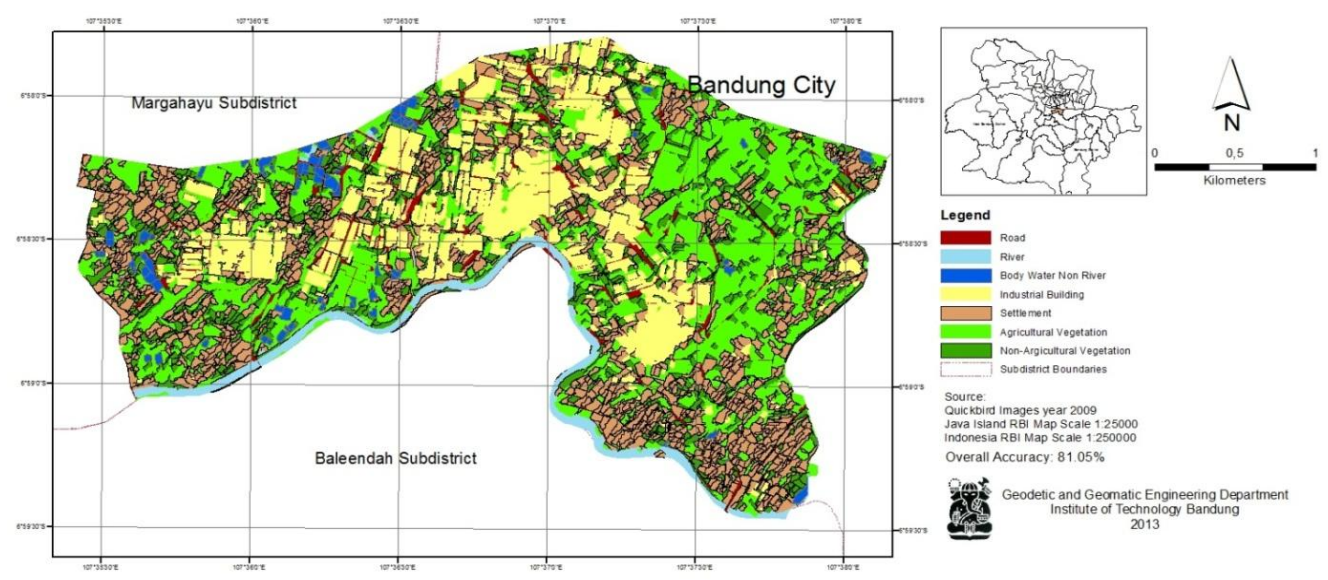

Figure 7. Classfication map using Quickbird image year 2009

Table 3. Class affected by water inundation

\begin{tabular}{cccc} 
Class & Total area $\left(\mathrm{m}^{2}\right)$ & $\begin{array}{c}\text { Total area affected by } \\
\text { water inundation }\left(\mathrm{m}^{2}\right)\end{array}$ & $\begin{array}{c}\text { Total area affected by } \\
\text { water inundation }(\%)\end{array}$ \\
\hline Industrial building & 1550783.16 & 466068.89 & 30.05 \\
Settlement & 2384622.72 & 258406.43 & 10.84 \\
Non-agriculture vegetation & 1275787.80 & 331590.75 & 25.99 \\
Agriculture vegetation & 2293716.60 & 848785.88 & 37.00 \\
\hline
\end{tabular}
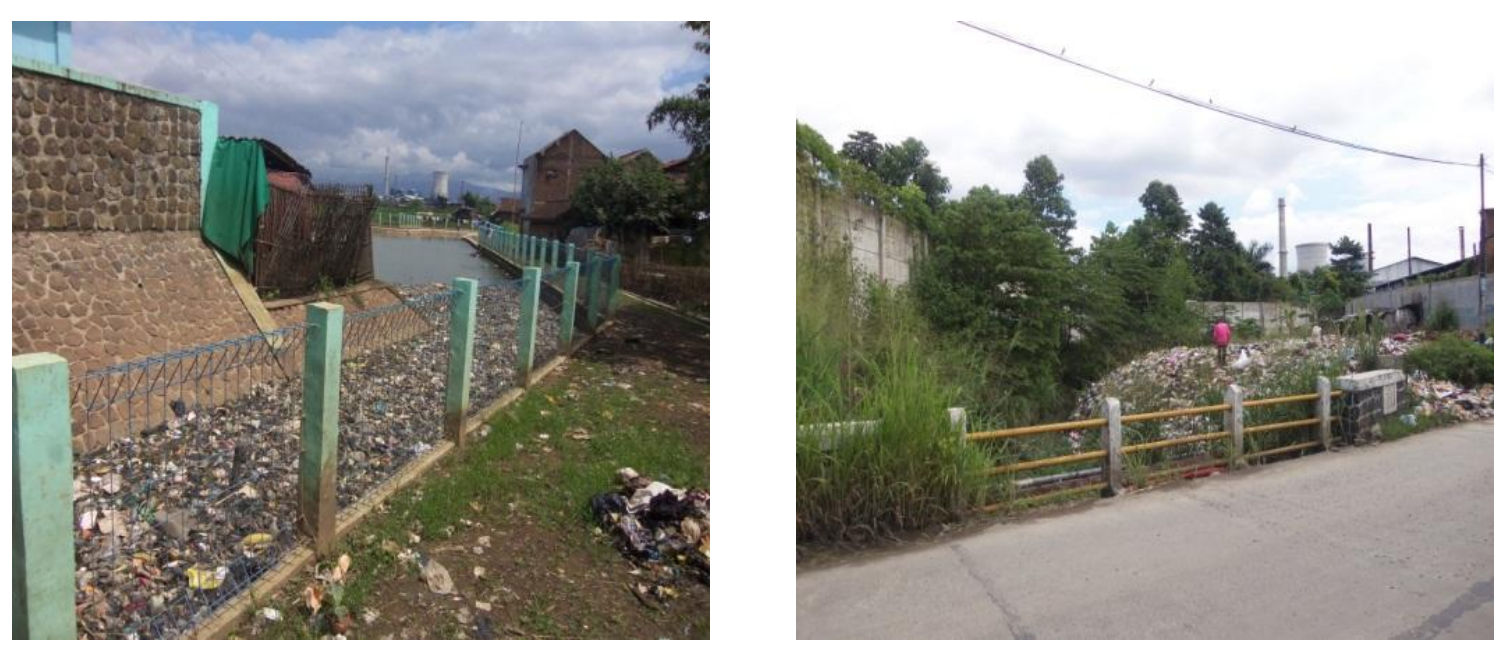

Figure 8. Bad drainage system in study area (source: ground check, 2013) 


\section{CONCLUSION}

Water inundation is a dynamic process that could causeflood. The changes in some areaswhichwere turned into industrial building class in land cover classification could reduce water infiltration area. The reduction of water infiltration area could cause the study area to beeasily affected by water inundation. Another reason why the study area is easily affected by water inundation is because of the topography of the study area that only lies at 662.5 meter above mean sea level with deviation range below 12.5 meter. The combination of Quickbird and ALOS PALSAR Imageshowsa better assesment for water inundation damage map. Object based image classification is used in Quickbird Image to produce land cover and the separation of water inundated and non-inundated using ALOS PALSAR Image by creatinglower and upper threshold has proofed satisfactionto assess water inundation in study area.

\section{ACKNOWLEDGMENT}

The author gratefully acknowledge the support from Mr. Ketut and Mr. Sony for providing Quickbird and ALOS PALSAR Imageand also for the advice and helpthroughouttthe working of this study. Authorwould also like to thanks PT. Barita Geoinformatika for definiens professional license, BIG for Java's RBI map and Mr. Hidayat from LIPI for his kind assistance in answering author questions regarding radar processing.

\section{REFERENCES}

Lillesand, T. M., \& Kiefer, R. W. 1979. Remote Sensing and Image Interpretation. John Wiley \& Sons. New York, United States of America.

Sarode, M. V., \& Deshmukh, P. R. 2011. Reduction of Speckle Noise and Image Enhancement of Images Using Filtering Technique. International Journal of Advancements in Technology. Vol.2. Issued 1, 30-38.

Twele, A., \& Martinis, S. 2009. Flood Detection Using TerraSAR-X Data. German Aerospace Center (DLR).

Harun, R. 2009. Remote Sensing Techniques Used for Flood Mapping in Bangladesh. Clark University.

Hidayat, H., Hoekman, D. H., Vissers, M. A., \& Hoitink, A. J. 2012. Flood Occurence Mapping of The Middle Mahakam Lowland Area Using Satellite Radar. Hydrology Earth System Science, 1805-1816.

Uddin, K., \& Shreshta, B. 2011. Assessing Flood and Flood Damage Using Remote Sesnign: A Case Study From Sunsary, Nepal. 3rd International Conference on Water \& Flood Management, 293-301.

Wasil, A. R. 2012. Identifikasi dan Perhitungan Luas Sawah dengan Citra Satelit Resolusi Tinggi Menggunakan Metode Object Based Image Analysis (OBIA). Skripsi Institut Teknologi Bandung. 47 pages.

Sanyal, J., \& Lu, X. X. 2004. Application of Remote Sensing in Flood Management with Special Reference to Monsoon Asia: A Review. Natural Hazards, 283-301. 